\title{
Experimental infection of yellow stingrays Urobatis jamaicensis with the marine leech Branchellion torpedinis
}

\author{
David P. Marancik ${ }^{1, *}$, Alistair D. Dove ${ }^{2}$, Alvin C. Camus ${ }^{1}$ \\ ${ }^{1}$ Department of Pathology, The University of Georgia College of Veterinary Medicine, Athens, Georgia 30602, USA \\ ${ }^{2}$ Department of Veterinary Services and Conservation Medicine, Georgia Aquarium Inc., Atlanta, Georgia 30313, USA
}

\begin{abstract}
Infestations of elasmobranchs by the marine leech Branchellion torpedinis can be problematic in aquaria and negatively affect host health. To better characterize the extent and pathogenesis of disease, 12 yellow stingrays Urobatis jamaicensis were infected with 1 or 3 leeches for $14 \mathrm{~d}$. Leeches were associated with anorexia, extensive cutaneous ulceration, decreased host packed cell volume (PCV) and serum total solids (TS), and mortality in 3 rays. Average decrease in host PCV positively correlated with ulcer size and parasite:host ratio. Average decrease in host serum TS positively correlated with parasite:host ratio. Blood chemistry and total white blood cell counts revealed no significant trends. Additional necropsy findings included gill and splenic pallor, pericardial edema, perirenal edema, and decreased hepatocellular lipid deposits. Microscopic evaluation of leeches demonstrated host erythrocytes and proteinaceous fluid within parasite intestines, confirming active blood feeding. Results indicate $B$. torpedinis has the potential to cause significant disease in elasmobranchs, including death in as few as $5 \mathrm{~d}$, and identifies ulcer size and parasite:host ratio as risk factors for disease. Elucidation of this host-parasite interaction helps characterize host response to parasites and facilitate care of parasitized elasmobranchs in aquarium and wild settings.
\end{abstract}

KEY WORDS: Branchellion torpedinis $\cdot$ Leech $\cdot$ Urobatis jamaicensis $\cdot$ Stingray $\cdot$ Infection

\section{INTRODUCTION}

Leeches are uncommonly implicated as significant parasites of fish (Burreson 2006), with sporadic reports of infestations in the literature. Epizootics involving wild and cultured fish describe large numbers of leeches attached to host skin and within the buccal cavity, with variable host disease and mortality. Severe oral ulcerations in Atlantic menhaden infested with Myzobdella lugubris in North Carolina appeared to have little overall effect on fish health (Sawyer \& Hammond 1973). A reported Zeylanicobdella arugamensis infection in tank-reared orange-spotted grouper Epinephelus coioides in the
Phillipines describes hundreds of leeches per fish but no associated host mortality (Cruz-Lacierda et al. 2000).

In contrast, upwards of 100 Austrobdella translucens parasitizing Australian sand whiting Sillago ciliate in stocked saltwater ponds resulted in the deaths of dozens of fish during successive years, presumably from exsanguination (Badham 1916). Loss of blood was also suggested in death of pink salmon Oncorhynchus gorbuascha fry parasitized by Pisicola salmonicitica in hatchery trays and Macrobdella decora and Haemopis grandis infection of wild brook trout in Maine (Earp \& Schwab 1954, Rupp \& Meyer 1954). 
Although host mortality is often presumed to be from blood loss, there may be additional factors affecting fish health during leech infections. Ectoparasites can represent stressors for fish and have been associated with decreased foraging (Milinski 1984), impaired anti-predator behavior (Milinski 1985), and reduced fecundity and growth (Iwama et al. 1999). For example, shorthorn sculpin Myxocephalus scorpius infected with the leech Malmiana brunnea showed significantly lower energetics than uninfected sculpin: Energy deficiencies attributed to leech feeding, tissue damage, and loss of metabolites, accounted for an energy loss of $\sim 750 \mathrm{cal} \mathrm{wk}^{-1}$ per gram of leech (Mace \& Davis 1972).

Leeches also play a role as vectors of disease in fish. Leech transmission of hematozoa including Trypanosoma spp. and Trypanoplasma spp. has been demonstrated in elasmobranchs and teleosts (Kruse et al. 1989, Burreson 2007). There is evidence implicating leeches as mechanical vectors of viruses in teleosts (Ahne 1985, Mulcahy et al. 1990, Faisal \& Schulz 2009) and speculation that attachment site ulcers (Faisal et al. 2011), and perhaps transmission by leeches themselves (Bragg et al. 1989), may predispose hosts to bacterial infections. Further physiologic and pathologic effects may exist in the leechhost relationship, but are yet unidentified.

Branchellion torpedinis is a marine leech that exclusively parasitizes elasmobranchs. Inadvertent introduction of $B$. torpedinis into closed aquarium settings is problematic, as parasites thrive under the low environmental stress and high host availability there. High leech fecundity and a lack of adequately studied, safe, and effective chemotherapeutics often make management difficult. Observations at the Georgia Aquarium, Atlanta indicated that B. torpedinis can negatively impact host health. Parasitism of multiple demersal and pelagic elasmobranch species often results in ulceration of skin, oropharynx, gill slits, and cloaca. Severe infestations have been associated with lethargy, anorexia, and death of the host.

Branchellion torpedinis belongs to the order Rhynchobdellida, which is comprised of the families Glossiphoniidae and Piscicolidae that parasitize freshwater, and freshwater and saltwater fish, respectively. These jawless leeches have a large caudal sucker for attachment and feed on host fluids through a strawlike proboscis inserted from a smaller, cranial sucker (Kearn 2004). Feeding is believed to be aided by salivary gland enzymes released into the tip of the proboscis, which enable penetration of host tissue and prevent hemostasis (Sawyer et al. 1991, Moser \& Desser 1995).
There is little information published on Branchellion torpedinis beyond its ecology and anatomy. We have been able to gain insight into its life history by observing the leech in aquaria under constant, $21^{\circ} \mathrm{C}$ environmental conditions. Unlike many leech species that are semi-permanent and dislodge from hosts after taking a blood meal to deposit cocoons onto vegetation and bottom substrate (Kearn 2004), B. torpedinis appears to remain attached to the host for the duration of its life. This prolonged, close contact with elasmobranch hosts may result in more extensive disease compared to leeches that act as temporary parasites (Burreson 2006). Cocoons are shed from the host into the bottom substrate and hatch in $\sim 30 \mathrm{~d}$. When removed from the host, $B$. torpedinis are short-lived in laboratory settings with survival lasting $<5 \mathrm{~d}$.

To better understand the pathogenic potential of Branchellion torpedinis and to characterize risk factors for disease, yellow stingrays Urobatis jamaicensis were used as an infection model. As non-schooling and sessile fish, these relatively small elasmobranchs adapt well to captivity and serve as suitable experimental models. Behavioral, biochemical and hematologic changes were monitored for $14 \mathrm{~d}$ during infection. Rays were necropsied on Day 14 and gross and microscopic lesion development was examined at attachment and feeding sites. Data were correlated with cutaneous damage and parasite:host weight ratios. Investigating these processes will enhance understanding of this host-parasite interaction and elasmobranch responses during disease states.

\section{MATERIALS AND METHODS}

\section{Experimental system}

Twelve wild-caught yellow stingrays were maintained individually in partitioned sections of a 3001 aquarium with sand substrate and recirculating artificial sea water (Instant Ocean ${ }^{\circledR}$ Sea Salt, Aquarium Systems) at $21^{\circ} \mathrm{C}, 30 \mathrm{ppt}$ salinity. The rays received alternating $12 \mathrm{~h}$ periods of light and dark and were fed a daily, rotating diet of shrimp, fish, and clam ad libitum, with amounts recorded. Physical exam and 3 repetitive skin scrapes prior to experimental trials revealed no ectoparasitic infections.

Rays were assigned to 2 experimental groups and allowed a minimum of $3 \mathrm{wk}$ to acclimate. Experimental group 'L1' consisted of 6 rays ( 2 males and 4 females, weight range 380 to $550 \mathrm{~g}$ ), each infected with 1 leech (weight range 632 to $763 \mathrm{mg}$ ). Experimental 
group 'L3' consisted of 6 rays ( 3 males and 3 females, weight range 315 to $475 \mathrm{~g}$ ), each infected with 3 leeches (combined weight range 1.831 to $2.145 \mathrm{~g}$ ). Leeches collected from captive elasmobranchs were transported directly to the laboratory for infection trials and manually placed on the dorsum of the rays. When rays were infected with 3 leeches, the leeches were placed approximately $8 \mathrm{~cm}$ apart.

\section{Sampling regimen}

Three randomly selected rays were subjected to the hematologic sampling regimen to ensure that repeated blood collection had no effect on hematology and chemistry values. After a $30 \mathrm{~d}$ recovery period, the 3 rays were randomly assigned to the experimental groups. Blood was collected 0, 7, and $14 \mathrm{~d}$ post-infection for serum chemistry, total WBC count, leukocyte differential, packed cell volume (PCV) and total solids (TS). On Day 3, only PCV and TS were run, to minimize the amount of blood collected and ensure the sampling regimen did not affect host physiology.

Blood collection was performed via intracardiac puncture using a $22 \mathrm{G} \times 1$ " needle and $3 \mathrm{ml}$ syringe (Kendall Monoject, Tyco Healthcare Group) under general anesthesia by immersion in $75 \mathrm{mg} \mathrm{l}^{-1} \mathrm{MS}-222$ buffered 1:1 by weight with sodium bicarbonate. The $400 \mu \mathrm{l}$ blood collected was divided between serum separator tubes (BD Microtainer ${ }^{\circledR}$ Gold Tubes) for blood chemistry, blood collection tubes containing $1.1 \mathrm{mg} \mathrm{ml}^{-1}$ lithium heparin (BD Microtainer ${ }^{\circledR}$ Green Tubes) for total WBC counts, and duplicate $40 \mathrm{~mm}$ glass microcapillary tubes containing ammonium heparin (Statspin ${ }^{\circledR}$ Microhematocrit Tubes) for PCV and TS. Blood smears were made immediately for each animal using whole blood and blood preserved in lithium heparin. All samples were processed within $1 \mathrm{~h}$ of collection.

\section{Serum chemistry}

Whole blood was allowed to clot and serum separator tubes were centrifuged for $10 \mathrm{~min}$ at $3000 \times \mathrm{g}$. Serum was pipetted off and analyzed on a Roche/ Hitachi P 800 Modular Analytics System (Roche Diagnostics) to measure total protein, urea nitrogen (BUN), albumin, alkaline phosphatase (ALP), alanine aminotransferase (ALT), aspartate aminotransferase (AST), glucose, creatine kinase (CK), cholesterol, triglycerides (TG), total bilirubin, uric acid, sodium, potassium, chloride, bicarbonate, calcium, phosphorus, and magnesium. Serum osmolality was calculated as $2 \mathrm{Na}\left(\mathrm{mEq} \mathrm{l}^{-1}\right)+\left(\right.$ Urea $\left.\left[\mathrm{mg} \mathrm{dl}^{-1}\right]\right) / 2.8+($ Glucose $[\mathrm{mg}$ $\left.\mathrm{dl}^{-1}\right]$ )/18 (Carlson 1997), as sufficient blood volumes for measured osmolarity could not be collected.

\section{Leukocyte count}

Twenty $\mu \mathrm{l}$ of heparinized whole blood was added to $1980 \mu \mathrm{l}$ of Natt-Herrick stain (ENG Scientific) adjusted for use in elasmobranchs by adding $0.3 \mathrm{~g}$ $\mathrm{NaCl}$ and $0.2 \mathrm{~g}$ urea to $10 \mathrm{ml}$ filtered Natt-Herrick's stock. Total numbers of granulocytes and mononuclear cells were determined manually using an improved Neubauer hemocytometer chamber and previously described methods (Arnold 2005). Thrombocytes were not included in leukocyte counts (Arnold 2005). An automated slide stainer (7120 Aerospray Slide Stainer ${ }^{\circledR}$, Wescor) was used to stain blood smears for differential counts.

\section{PCV and TS}

Microcapillary tubes were centrifuged for 3 min at $3000 \times g$ in a CritSpin ${ }^{\circledR}$ Microhematocrit Centrifuge (Statspin). PCV were interpreted by measuring the erythrocyte-plasma interface on a capillary tube reader (Statspin ${ }^{\circledR}$, Iris Sample Processing). TS were measured using a hand-held refractometer (Reichert Analytical Instruments).

\section{Necropsy}

Three rays died prior to Day 14 and were necropsied immediately. Based on scheduled monitoring of animals, the interval between death and necropsy ranged from 1 to $5 \mathrm{~h}$. Rays remaining at Day 14 were euthanized by immersion in $250 \mathrm{mg} \mathrm{l}^{-1} \mathrm{MS}-222$ (Finquel, Argent Chemical Laboratories) and complete necropsies were performed. Skin scrapes and gill clips were evaluated by light microscopy. The length and width of skin ulcers produced at leech attachment sites were measured to the nearest millimeter and total area of ulceration was calculated. Leeches, leech attachment sites, normal skin, and representative samples of brain, gill, thyroid gland, heart, liver, spleen, kidney, pancreas, gastrointestinal tract, epigonal organ, and rectal gland were examined. Tissues were fixed in $10 \%$ neutral-buffered formalin and $4 \mu \mathrm{m}$ sections were cut and stained with hema- 
toxylin and eosin (H\&E) for microscopic evaluation. Sections of ulcerated skin were additionally stained with Lillie-Twort Gram's stain. Rays were weighed on a digital scale (Ohaus) at Day 0 and at necropsy.

\section{Statistical analyses}

Statistical analysis was performed using Minitab version 15.0. A 2-sample Wilcoxon rank sum (MannWhitney) test was used to compare ulcer size with leech number. A Pearson correlation coefficient (Pearson's r) was applied to the correlation of ulcer area, beginning leech:host weight ratio, PCV decrease, and TS decrease. A p-value $<0.05$ was considered significant.

\section{RESULTS}

Leeches attached within seconds and remained on the dorsum of rays throughout the $14 \mathrm{~d}$ challenge. Four of 12 rays were observed rubbing on substrate for up to $24 \mathrm{~h}$ following attachment. Anorexia was a common clinical sign. Average total feed intake in the L1 group decreased $25 \%$ by Day 7 and $50 \%$ by Day 14. Weight loss of 2 to $4 \mathrm{~g}$ was observed in 2 rays with an average of $3 \mathrm{~g}$. Feed intake in the L3 group decreased $75 \%$ by Day 7 and $100 \%$ by Day 14 . Weight loss of 2 to $7 \mathrm{~g}$ was observed in 4 rays with an average of $5 \mathrm{~g}$.

\section{Fish pathology and mortality}

Variably sized cutaneous ulcers associated with the leech caudal sucker were observed in all rays (Fig. 1A). Peripherally surrounding attachment sites were variable numbers of hemorrhages, $1 \mathrm{~mm}$ in diameter, presumed to be leech feeding sites (Fig. 1A). Cumulative ulcer size averaged $2.54 \mathrm{~cm}^{2}$ (range 1.6 to $5.25 \mathrm{~cm}^{2}$ ) and $5.83 \mathrm{~cm}^{2}$ (3.1 to $\left.12 \mathrm{~cm}^{2}\right)$ in the L1 and L3 groups, respectively. The 3 rays that died prior to Day 14 exhibited the largest areas of skin ulceration. One L1 ray that died on Day 11 had an ulcer area of $5.25 \mathrm{~cm}^{2}$. Two rays from L3 that died on Days 5 and 7 had ulcer areas of 12 and $6 \mathrm{~cm}^{2}$, respectively. Cumulative ulcer size correlated with leech number (MannWhitney test, $p=0.037$ ), but did not significantly correlate with leech weight (Pearson's $r=-0.539, \mathrm{p}=0.070$ ).

Microscopically, attachment site ulcers began as discrete, well-demarcated foci of epithelial erosion bordered by a narrow margin of hyperplasia. Lesions progressed to full thickness necrosis of epithelium and superficial dermis overlaid by a thick layer of cellular and acellular debris (Fig. 1B). Hemorrhage and intensely eosinophilic fluid were widespread within epithelial, dermal and hypodermal tissue, with variable infiltration by scattered to moderate numbers of fine-eosinophilic granulocytes, fewer coarse-eosinophilic granulocytes, and scattered lymphocytes, plasma cells, and macrophages. Mixed populations of Gram-negative and Gram-positive rods and cocci were present histologically on the surface of ulcers in 4 of 12 rays, with dissemination into dermal tissue of 1 individual. Although bacterial cultures were not performed, no bacteria, inflammatory infiltrates, or necrosis were present microscopically in internal organs to indicate systemic infection. In 5 of 12 rays, there was multifocal skeletal muscle degeneration and necrosis. Affected areas were characterized by pale, shrunken muscle bundles containing individual fibers exhibiting loss of cross striations, as well as sarcoplasmic coagulation, vacuolation, and fragmentation. Nuclei were pyknotic to absent (Fig. 1C).

Presumed feeding site lesions consisted of welldemarcated, $1 \mathrm{~mm}$ diameter oblique tracks extending through the epidermis and dermis (Fig. 1D). Tracks were filled with erythrocytes, proteinaceous fluid, variable numbers of fine-eosinophilic granulocytes, and few coarse-eosinophilic granulocytes. Although inflammatory infiltrates confined to proboscis tracks were occasionally intense, inflammation and necrosis in the surrounding tissue was minimal.

Additional gross necropsy findings included approximately 5 to $30 \mathrm{ml}$ of clear, yellow-brown fluid within the pericardial (Fig. 1E) and coelomic cavities of 5 rays. Gill and splenic pallor was present in 8 animals. The livers of 4 rays were small, dark, and firm. Internal microscopic changes included decreased hepatocellular lipid vacuolation and decreased prominence of splenic red pulp, in 4 and 6 rays, respectively.

The intestinal tract of leeches contained ingested host erythrocytes, proteinaceous fluid, and granulocytes (Fig. 1F).

\section{Hematology}

Average PCV for the 3 rays subjected to the prechallenge bleeding regimen remained between 30 and $32 \%$ on Days $0,3,7$, and 14 (Fig. 2A). Rays in both experimental groups exhibited progressively decreasing PCVs at all consecutive time points (Fig. 2A). Decrease in PCVs between Days 0 and 14, 


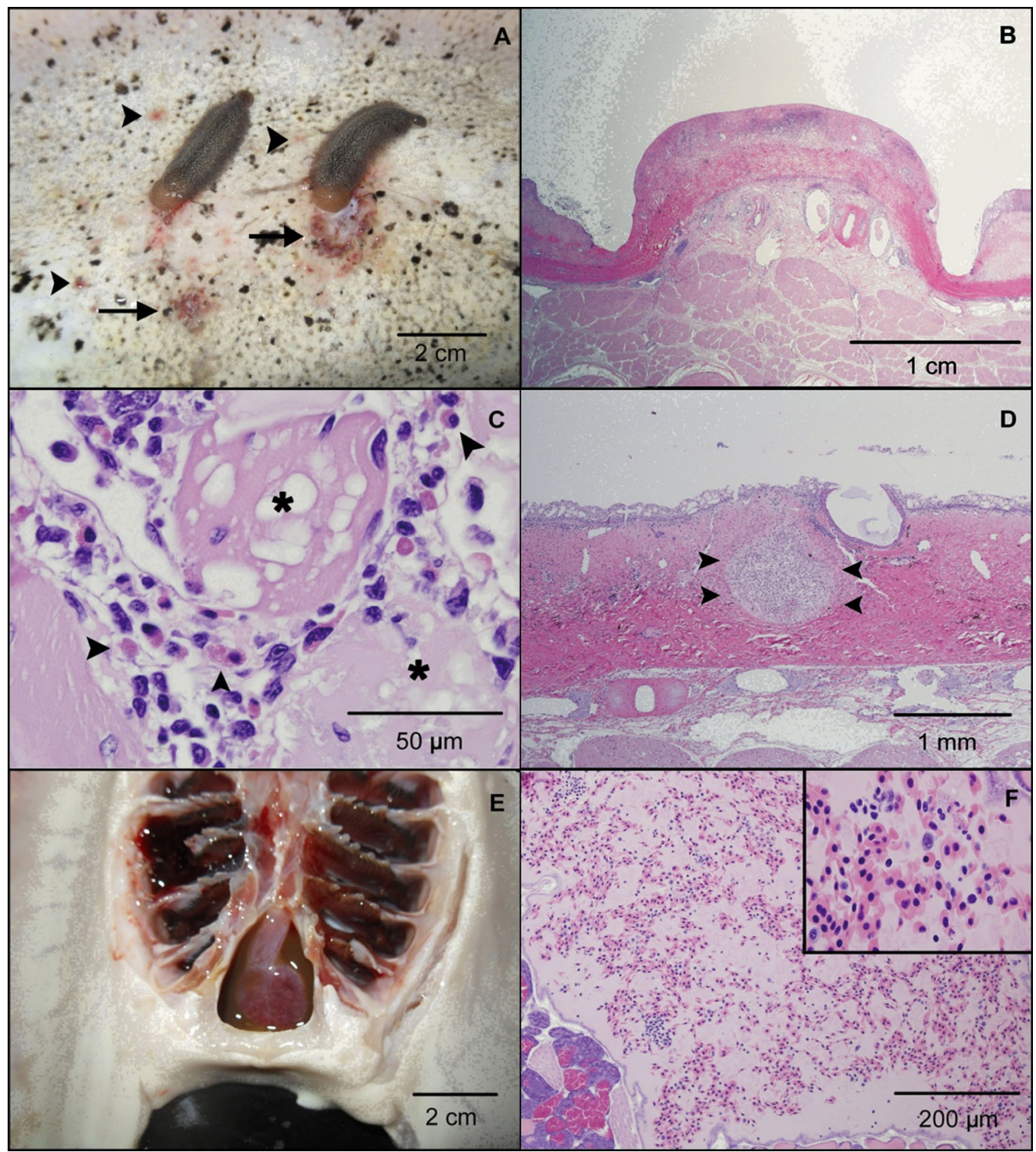

Fig. 1. Infestation of yellow stingrays Urobatis jamaicensis by the marine leech Branchellion torpedinis: gross and microscopic necropsy findings. (A) Two leeches attached to the dorsum of a yellow stingray. Caudal suckers are associated with epidermal ulceration (arrows). Leeches are surrounded by multiple, pinpoint hemorrhages presumed to be feeding sites (arrowheads). (B) Typical microscopic appearance of coalescing, button-shaped ulcerations associated with caudal sucker attachment sites. (C) Inflammatory infiltrates of fine-eosinophilic granulocytes (arrowheads) associated with skeletal muscle degeneration and necrosis (asterisks). Skeletal muscle bundles are pale with vacuolated sarcoplasm that lack normal cross-striations. (D) Microscopic appearance of subepidermal tracks produced by the proboscis at feeding sites (arrowheads). Areas are well demarcated, filled with debris, erythrocytes and proteinaceous fluid. Note minimal inflammatory reaction in the surrounding dermis. (E) Pericardial fluid accumulation associated with decreased packed cell volume and serum total solids. (F) Section of leech intestine filled with abundant red blood cells and granulocytes admixed with proteinaceous fluid. Insert: 100x view depicting erythrocytes and proteinaceous fluid within leech intestine. Staining, Panels B-D,F: H\&E

or last recorded value prior to mortality, averaged $18 \%$ for the L1 group and $25 \%$ for the L3 group. The 3 rays that died prior to Day 14 exhibited marked decreases in PCV. The L1 ray that died on Day 11 had a PCV of $26 \%$ on Day 0 and a last recorded value of $7 \%$ on Day 7 . The 2 L3 rays that died on Days 5 and
7 had baseline PCVs of 30 and $33 \%$, respectively. Both had last recorded values of $6 \%$. Declining PCV levels for the L1 and L3 groups positively correlated with leech:host weight ratios (Pearson's $r=0.731, p=$ 0.007) (Fig. 3A) and ulcer areas (Pearson's $r=0.370$, $\mathrm{p}=0.026$ ) (Fig. 3B). 


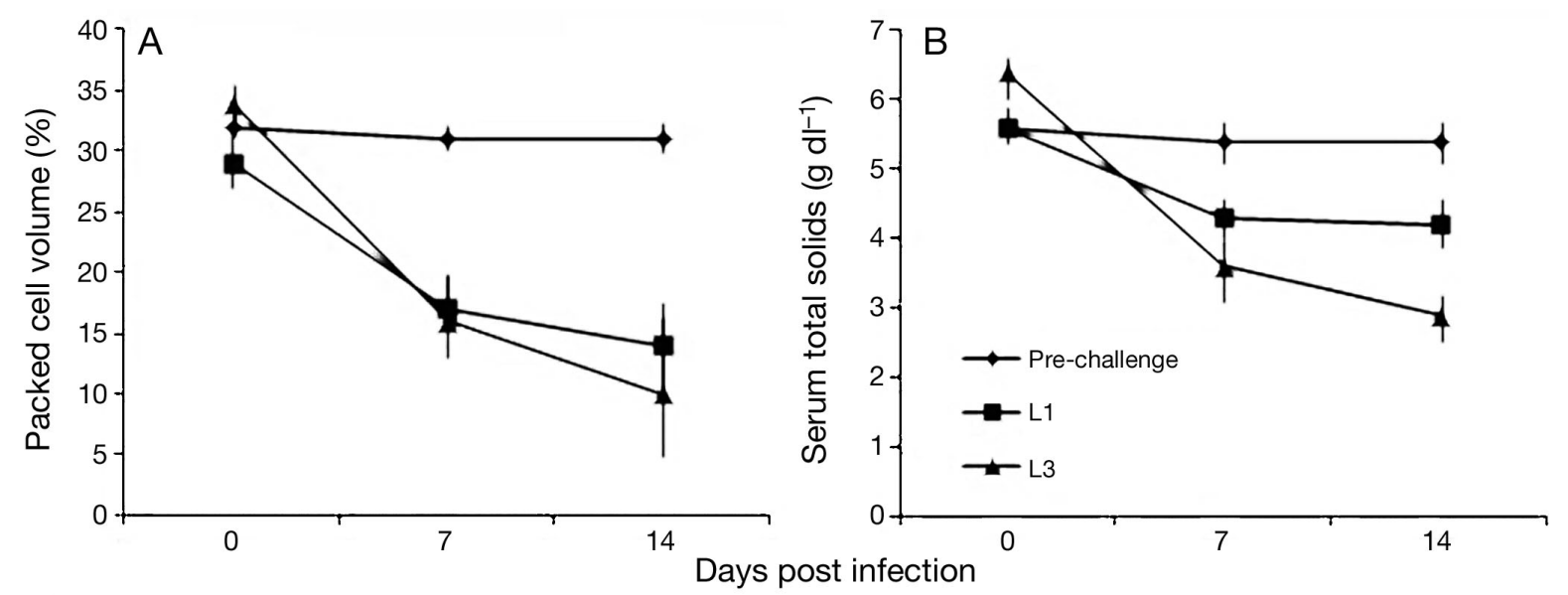

Fig. 2. Hematologic trends in (A) packed cell volume (PCV) and (B) serum total solids for the pre-challenge group of yellow stingrays $(n=3)$, L1 group infected with 1 marine leech $(n=6)$, and L3 group infected with 3 leeches $(n=6)$. Day 3 values are not represented to allow consistency between $x$-axis intervals
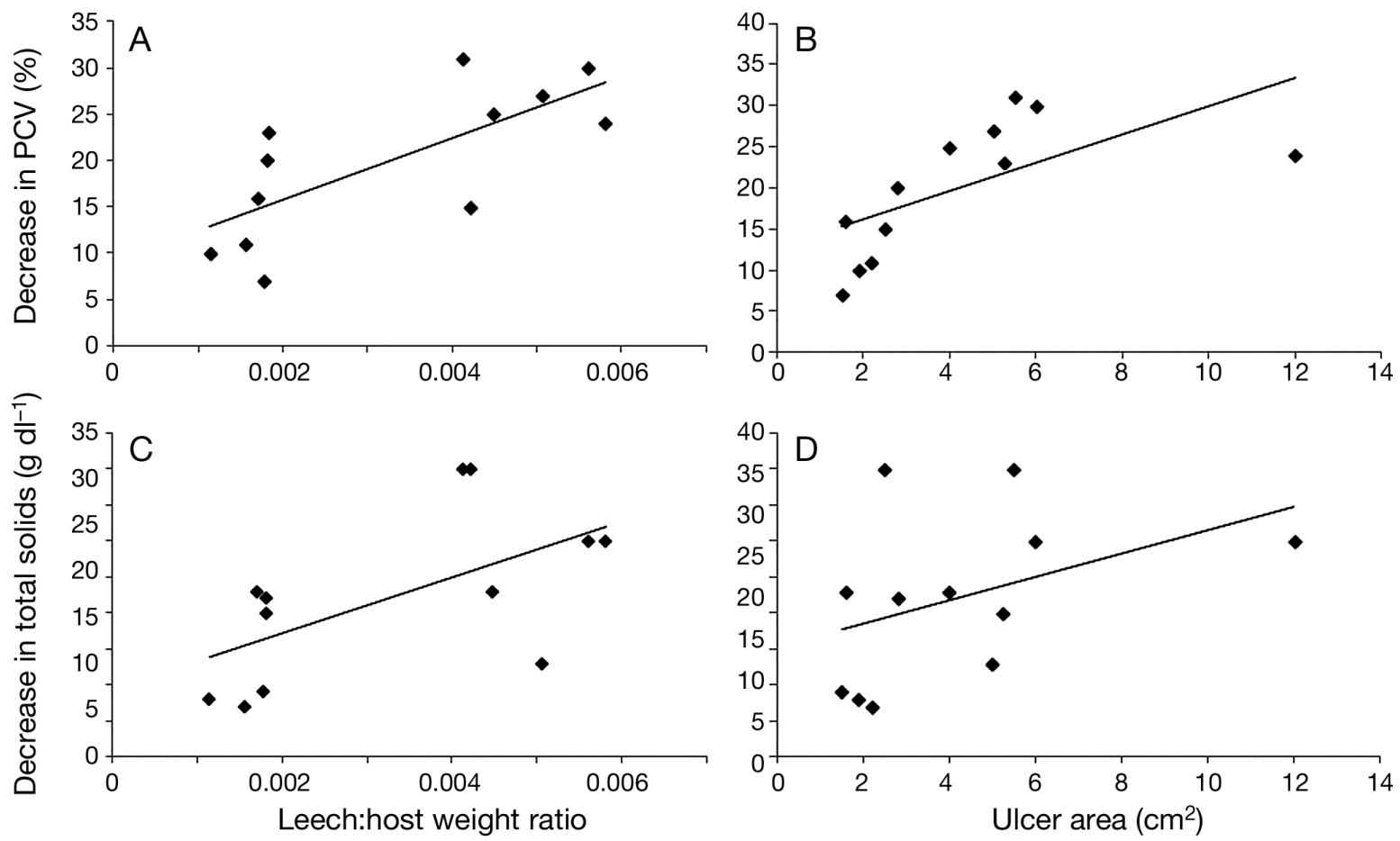

Fig. 3. Decrease in host PCV and (A) leech:host weight ratio (Pearson's $r=0.731, p=0.007$ ) and (B) ulcer area (Pearson's $r=0.370, p=0.026$ ). Decrease in host serum total solids and $(C)$ leech:host weight ratio (Pearson's $r=0.592, p=0.042)$ and $(D)$ ulcer area (Pearson's $r=0.415, p=0.180$ )

Average TS for pre-challenge animals remained between 5.4 and $5.6 \mathrm{~g} \mathrm{dl}^{-1}$ throughout the study, but declined progressively in both experimental groups (Fig. 2B). Average decreases in TS of 1.4 and $2.9 \mathrm{~g}$ $\mathrm{dl}^{-1}$ occurred in the L1 and L3 groups, respectively, between Days 0 and 14, or the last recorded timepoint. TS decrease was positively correlated with decrease in PCV (Pearson's $r=0.587, \mathrm{p}=0.045$ ), leech:host weight ratio (Pearson's $r=0.592, p=0.042$ ) (Fig. 3C), and ulcer area (Pearson's $r=0.415, p=$ 0.180) (Fig. 3D), although the last was not statistically significant.

Total WBC counts for the pre-challenge, L1 and L3 groups showed no significant trends during the study. Observed average WBC counts for the prechallenge group were 18260,19030 , and 18920 
WBC $\mu^{-1}$ on Days 0,7 and 14 , respectively. The average WBC count for the L1 group was 18040, 18070 , and $17600 \mathrm{WBC}^{-1}$ on Days 0, 7 and 14, respectively. The average WBC count for the L3 group was 18 736, 17182 , and $19470 \mathrm{WBC} \mu^{-1}$ on Days 0,7 and 14 , respectively.

Significant lysis of white and red blood cells was present on blood smears. Differential leukocyte counts could not be reliably interpreted for a statistically useful number of samples and are not included in these results.

\section{Serum chemistry}

Serum urea nitrogen, albumin, ALP, ALT, AST, glucose, CK, cholesterol, TG, total bilirubin, uric acid, sodium, potassium, chloride, bicarbonate, calcium, phosphorous, magnesium, and calculated osmolality showed no significant trends between Days 0, 7 and 14 . The mean, median and range of 15 pre-challenge and experimental Day 0 chemistry values are reported in Table 1.

\section{DISCUSSION}

Infection by 1 or 3 Branchellion torpedinis leeches led to a number of pathologic changes in yellow stingrays and was associated with host mortality in $<14 \mathrm{~d}$. Large areas of skin ulceration began as button-shaped areas of necrosis that conformed to the caudal sucker, suggesting lesions resulted from pressure induced ischemia. Hydrostatic pressures of $-90 \mathrm{~cm} \mathrm{H}_{2} \mathrm{O}$ have been recorded from the caudal sucker of Placobdella parasitica (Gradwell 1972) and it is hypothesized that contact with host skin may be enhanced by secretion of hydrolytic enzymes that dissolve the epithelial mucous layer (Appy \& Cone 1982). Attachment of B. torpedinis typically resulted in skin sloughing within $7 \mathrm{~d}$, followed by relocation of leeches to an adjacent area of intact epithelium. Overall tissue damage and inflammatory changes associated with caudal sucker attachment sites were significantly more pronounced compared to feeding sites, indicating pressure necrosis caused by the caudal sucker is highly traumatic to elasmobranch tissue, compared to the more restrained proboscis insertion.

Ulceration area was determined by measurements of gross epithelial loss. Pinpoint hemorrhages at presumed feeding sites were not included in calculating lesion size, but may have contributed to the physio-
Table 1. Mean, median, and ranges for the baseline serum chemistry values of captive yellow stingrays $(n=15)$ prior to challenge with the marine leech Branchellion torpedinis. Female and male results are pooled as they did not differ statistically. BUN: blood urea nitrogen; ALP: alkaline phosphatase; ALT: alanine aminotransferase; AST: aspartate aminotransferase; CK: creatine kinase; TG: triglycerides

\begin{tabular}{|c|c|c|c|}
\hline Analyte & Mean & Median & Range \\
\hline Total protein $\left(\mathrm{g} \mathrm{dl}^{-1}\right)$ & 2.9 & 2.2 & $1.3-3.8$ \\
\hline $\mathrm{BUN}\left(\mathrm{mg} \mathrm{dl}^{-1}\right)$ & 1028 & 1038 & $834-1367$ \\
\hline Albumin $^{\mathrm{a}}\left(\mathrm{g} \mathrm{dl}^{-1}\right)$ & - & - & $<0.2-0.5$ \\
\hline $\operatorname{ALP}\left(U^{-1}\right)$ & 12 & 10 & $5-25$ \\
\hline $\operatorname{ALT}^{\mathrm{a}}\left(\mathrm{U} \mathrm{l}^{-1}\right)$ & $<0.4$ & - & $<0.4-13$ \\
\hline Glucose $\left(\mathrm{mg} \mathrm{dl}^{-1}\right)$ & 30 & 32 & $18-38$ \\
\hline Sodium (mmol l-1 $\left.{ }^{-1}\right)$ & 265 & 266 & $247-277$ \\
\hline Potassium $\left(\mathrm{mmol} \mathrm{l}^{-1}\right)$ & 5.1 & 4.7 & $3.9-8.5$ \\
\hline Chloride $\left(\mathrm{mmol} \mathrm{l}^{-1}\right)$ & 275 & 277 & $253-296$ \\
\hline Bicarbonate $\left(\mathrm{mmol} \mathrm{l}^{-1}\right.$ & 3.5 & 4 & $3-4$ \\
\hline Calcium (mg dl $\left.{ }^{-1}\right)$ & 16.6 & 17.3 & $12.7-18.8$ \\
\hline Phosphorus (mg dl ${ }^{-1}$ ) & 3.4 & 3.4 & $2.8-4.7$ \\
\hline Magnesium (mg dl $\left.{ }^{-1}\right)$ & 3.8 & 3 & $1.7-10$ \\
\hline $\operatorname{AST}\left(\mathrm{U} \mathrm{l}^{-1}\right)$ & 51 & 32 & $8-113$ \\
\hline $\mathrm{CK}\left(\mathrm{U} \mathrm{l}^{-1}\right)$ & 953 & 979 & $232-2368$ \\
\hline Cholesterol $\left(\mathrm{mg} \mathrm{dl}^{-1}\right)$ & 145 & 253 & $50-282$ \\
\hline $\mathrm{TG}\left(\mathrm{mg} \mathrm{dl}^{-1}\right)$ & 241 & 153 & $84-546$ \\
\hline Total bilirubin $\left(\mathrm{mg} \mathrm{dl}^{-1}\right)$ & 0 & 0 & 0 \\
\hline $\operatorname{Uric}_{\operatorname{acid}^{\mathrm{a}}}\left(\mathrm{mg} \mathrm{dl}{ }^{-1}\right)$ & - & - & $<0.2$ \\
\hline Osmolality (Osm kg$\left.{ }^{-1}\right)$ & 901 & 926.9 & $803.2-1028.1$ \\
\hline \multicolumn{4}{|c|}{$\begin{array}{l}\text { analyte values fell below instrument measurement } \\
\text { ranges and mean and median values could not be calcu- } \\
\text { lated }\end{array}$} \\
\hline
\end{tabular}

logic effects of ulceration, including blood loss. Ulcers ranged from 1.6 to $12 \mathrm{~cm}^{2}$ and positively correlated with leech number, but ulcer size was not dependent on leech weight. Although larger leeches were anecdotally observed producing larger attachment site ulcers, this lack of correlation may have been affected by other factors, including leech behavior. In 5 of 6 rays from the L3 group, leeches congregated, resulting in larger, coalescing ulcers. As has been suggested for other parasites, leech congregation may support reproductive strategies or represent shared or preferential feeding sites (SolerJiménez \& Fajer-Avila 2012). Leeches also exhibited mobility that contributed to larger ulcer size as described above. The largest ulcer, at $12 \mathrm{~cm}^{2}$, was produced by 3 leeches with the lowest combined weight as they migrated down the wing of the ray.

Inflammation at attachment and feeding sites consisted predominantly of fine eosinophilic granulocytes. Although there is no complete agreement regarding classification of elasmobranch leukocytes, there is evidence to suggest their granulocytes have secretory (Hine \& Wain 1987) and phagocytic (Hyder et al. 1983) roles in inflammation. Fine- 
eosinophilic granulocytes may play a role in host attempts to eliminate parasites (Dezfuli et al. 2000). Degranulation and release of phosphatases and esterases (Hine \& Wain 1987) from granulocytes may contribute to necrosis observed in host dermal and subdermal tissue.

Superficial bacteria were evident in ulcers of 4 rays with extension of bacteria into deeper dermal tissues of one. Skin trauma is often hypothesized as an infection route for pathogens including bacteria, viral, and fungal agents (Burreson 2006). Although there were no gross or microscopic changes to suggest bacterial sepsis during the course of the study, ulceration must be considered a potential risk factor for invasion by secondary pathogens.

PCV, TS, total WBC counts, and serum chemistry in pre-challenge animals showed minimal variability from experimental Day 0 values, suggesting blood sampling had minimal effect on blood work results.

Three rays that died prior to Day 14 exhibited rapid declines in PCV. Rapid blood loss may be more poorly tolerated than slow declines that permit time for physiologic adaptation (Caroll et al. 1984). Despite a lack of published reference ranges for yellow stingrays, the dramatic drop in PCV, coupled with pale gills and viscera, is consistent with anemia.

As anticipated, decrease in PCV correlated with ulcer size and parasite:host weight ratios. Ulcers were associated with significant dermal hemorrhage and edema suggesting blood loss from lesion sites. Three rays that died prior to Day 14 had the largest areas of skin ulceration, indicating ulcer size is a significant contributing factor to mortality. Correlation of decreasing PCV with parasite:host weight ratios suggests parasite burden as a risk factor for disease. Furthermore, host erythrocytes within the leech gut confirms blood feeding by Branchellion torpedinis.

Progressive decrease in TS was evident in all rays at all timepoints. Pericardial and coelomic fluid was associated with TS measuring less than $3.4 \mathrm{~g} \mathrm{dl}^{-1}$, suggesting low serum oncotic pressure may have been associated with effusion. Although free coelomic and pericardial fluid can be intermittently encountered during elasmobranch necropsies (D. Marancik pers. obs.), the fluid was more abundant and darker than that normally found, and was interpreted as abnormal.

Variation was present between TS measured by refractometry and total protein recorded by the Roche analyzer. In mammals, TS are used as an estimate of total protein, although TS are expected to be higher in all species (George 2001). Yellow stingray TS measured by refractometry averaged $5.6 \mathrm{~g} \mathrm{dl}^{-1}$ on
Day 0 and $3.6 \mathrm{~g} \mathrm{dl}^{-1}$ for the last recorded value. Total proteins measured on the Roche analyzer averaged $2.9 \mathrm{~g} \mathrm{dl}^{-1}$ on Day 0 and $1.4 \mathrm{~g} \mathrm{dl}^{-1}$ as a last recorded value. This dissimilarity is consistent with a previous study in cownose stingrays (Ferreira et al. 2010) and supports the premise that TS do not adequately correlate with total protein in elasmobranchs. There are indications that elasmobranchs produce little or no serum albumin (Metcalf \& Gemmel 2005), which may account for the disparity. In addition to protein, refractometry results may be affected by the high concentrations of blood urea and trimethylamine oxide (TMAO) (Olson 1999) present in elasmobranchs.

The cause of decreased TS is likely multifactorial. Proteinaceous fluid present in leech intestine and correlation between TS decrease and parasite:host ratios suggest that leech feeding contributed to loss of serum analytes. Loss of blood and tissue fluid at ulcer sites may also have contributed, although statistical correlation with ulcer size was not significant. Extracellular fluid shifts to vascular spaces have been described in elasmobranchs secondary to hemorrhage and acute hypovolemia (Caroll et al. 1984). The impact of similar homeostatic mechanisms on TS, secondary to blood loss in these parasitized rays, is unknown. Anorexia may have also influenced TS. Protein-deficient diets and anorexia of $>14 \mathrm{~d}$ negatively affects urea production and osmoregulation in elasmobranchs (Leech et al. 1979, Armour et al. 1993, Wood 2010). Food intake was reduced $50 \%$ in L1 rays and $100 \%$ in L3 rays by Day 14 . Negative energy balance was supported by weight loss in 6 rays and loss of hepatocellular lipid deposits typically present in elasmobranchs in 4 rays.

Serum chemistries traditionally measure the serum components comprising TS. Serum chemistries were not significantly altered in this study, despite significant decreases in TS in all rays. This discrepancy suggests the refractive index was affected by one or more analytes not accounted for by the Roche analyzer. This highlights the difficulty in assessing metabolic trends in elasmobranchs using traditional analytical methods. Past studies indicate elasmobranch metabolism is fundamentally different from the metabolism of mammals and boney fish. Ketone bodies are described as important metabolites for elasmobranchs, with less utilization of amino acids and carbohydrates, and negligible metabolism of lipids (Ballantyne 1997). Traditional serum chemistry panels may not include metabolically active elements more indicative of elasmobranch physiology.

Assessing serum osmolality was of particular interest in this study. Disruption of skin epithelium is often 
hypothesized as causing osmoregulatory disturbances in fish (Ibrahem \& Mesalhy 2010). Marine elasmobranchs maintain extracellular fluids that are hyperosmotic to seawater due to high concentrations of urea and TMAO (Olson 1999). Plasma sodium and chloride levels are lower than those found in seawater (Shuttleworth 1988). Theoretically, skin ulceration could result in unabated fluid shifts, specifically, water and electrolyte influx and urea and TMAO efflux. No changes in electrolytes or calculated osmolality were detected in this study. This implies adequate compensation through normal osmoregulatory mechanisms, or that no significant changes in osmotic homeostasis occurred.

Although inflammation was present at feeding and attachment sites, Branchellion torpedinis infection did not elicit a systemic inflammatory response, as indicated by a lack of significant changes in total WBC values throughout the experiment. However, it is difficult to interpret changes without differential WBC percentages. Despite using multiple techniques, distortion and lysis of leukocytes precluded critical interpretation of blood smears. Similar difficulties were reported by Arnold (2005).

Findings in this study indicate Branchellion torpedinis has the potential to be an important parasite of certain elasmobranch species. In yellow stingrays, relatively low numbers of leeches produced significant morphologic and physiologic changes, including skin ulceration, anemia and decreased total solids, as well as death in <14 d. Progression of skin lesions and the trends in blood values suggest infections extending past Day 14 would result in further host pathology and mortality. Extended trials with lower numbers of parasites would help assess host physiologic, immunologic, and regenerative host responses. Larger elasmobranch species that may be more resistant to pathogenic effects of leeches may serve as more suitable models for chronic infection.

\section{LITERATURE CITED}

Ahne W (1985) Argulus foliaceus L. and Piscicola geometra L. as mechanical vectors of spring viraemia of carp virus (SVCV). J Fish Dis 8:241-242

> Appy RG, Cone DK (1982) Attachment of Myzobdella lugubris (Hirudinea: Piscicolidae) to Logperch, Percina caprodes, and Brown Bullhead, Ictalurus nebulosus. Trans Am Microsc Soc 101:135-141

> Armour KJ, O'Toole LB, Hazon N (1993) The effects of dietary protein restriction on the secretory dynamics of 1-hydroxycorticosterone and urea in the dogfish, Scyliorhinus canicula: A possible role for 1-hydroxycorticosterone in sodium retention. J Endod 138: $275-282$
Arnold JE (2005) Hematology of the sandbar shark, Carcharhinus plumbeus: standardization of complete blood count techniques for elasmobranchs. Vet Clin Pathol 34: 115-123

Badham C (1916) On an ichthyobdellid parasitic on the Australian sand whiting (Sillago ciliate). Q J Microsc Sci 62: $1-41$

Ballantyne JS (1997) Jaws: the inside story. The metabolism of elasmobranch fishes. Comp Biochem Physiol B 118: 703-742

Bragg RR, Oosthuizen JH, Lordan SM (1989) The leech Batrachobdelloides tricarinata Blanchard 1987 (Hirudinea:Glossiphoniidae) as possible reservoir of the rainbow trout pathogenic Streptococcus spp. Onderstepoort J Vet Res 56:203-204

Burreson EM (2006) Phylum Annelida: Hirudinea as vectors and disease agents. In: Woo PTK (ed) Fish diseases and disorders, Vol 1. CABI, Wallingford, p 566-591

Burreson EM (2007) Hemoflagellates of Oregon marine fishes with the description of new species of Trypanosoma and Trypanoplasma. J Parasitol 93:1442-1451

Carlson G (1997) Fluids, electrolytes and acid-base balance. In: Kaneko JJ, Harvey JW, Bruss ML (eds) Clinical biochemistry of domestic animals, 5th edn. Academic Press, San Diego, CA, p 485-573

Carroll RG, Opdyke DF, Keller NE (1984) Vascular recovery following hemorrhage in the dogfish shark Squalus acanthias. Am J Physiol 246:R825-R828

Cruz-Lacierda ER, Toledo JD, Tan-Fermin JD, Burreson EM (2000) Marine leech (Zeylanicobdella arugamensis) infestation in cultured orange-spotter grouper, Epinephelus coioides. Aquaculture 185:191-196

> Dezfuli BS, Simoni E, Rossi R, Manera M (2000) Rodlet cells and other inflammatory cells of Phoxinus phoxinus infected with Raphidascaris acus (Nematoda). Dis Aquat Org 43:61-69

> Earp BJ, Schwab RL (1954) An infestation of leeches on salmon fry and eggs. Prog Fish-Cult 16:122-124

Faisal M, Schulz CA (2009) Detection of Viral Hemorrhagic Septicemia virus (VHSV) from the leech Myzobdella lugubris Leidy, 1851. Parasit Vectors 2:45

Faisal M, Schulz C, Eissa A, Whelan G (2011) High prevalence of buccal ulcerations in largemouth bass, Micropterus salmoides (Centrarchidae) from Michigan inland lakes associated with Myzobdella lugubris Leidy 1851 (Annelida: Hirudinea). Parasite 18:79-84

Ferreira CM, Field CL, Tuttle AD (2010) Hematological and plasma biochemical parameters of aquarium-maintained cownose rays. J Aquat Anim Health 22:123-128

> George JW (2001) The usefulness and limitations of handheld refractometers in veterinary laboratory medicine: a historical and technical review. Vet Clin Pathol 30: 201-210

Gradwell N (1972) Behaviors of the leech, Placobdella, and transducer recordings of suctorial pressures. Can J Zool 50:1325-1332

Hine PM, Wain JM (1987) The enzyme cytochemistry and composition of elasmobranch granulocytes. J Fish Biol 30:465-475

> Hyder SL, Cayer ML, Pettey CL (1983) Cell types in peripheral blood of the nurse shark: an approach to structure and function. Tissue Cell 15:437-455

> Ibrahem MD, Mesalhy S (2010) Determining the safety and suitability of fluorescein dye for characterization of skin ulcerations in cultured Nile tilapia (Oreochromis niloti- 
cus) and African sharptooth catfish (Clarias gariepinus). J Adv Res 1:361-366

Iwama GK, Vijayan MM, Forsyth RB, Ackerman PA (1999) Heat shock proteins and physiological stress in fish. Am Zool 39:901-909

Kearn G (2004) Leeches, lice and lampreys: a natural history of skin and gill parasites of fishes. Springer, Dordrecht, p 130-153

Kruse P, Steinhagen D, Körting W (1989) Development of Trypanoplasma borreli (Mastigophora: Kinetoplastida) in the leech vector Piscicola geometra and its infectivity for the common carp, Cyprinus carpio. J Parasitol 75: $527-530$

Leech AR, Goldstein L, Cha C, Goldstein JM (1979) Alanine biosynthesis during starvation in skeletal muscle of the spiny dogfish, Squalus acanthias. J Exp Zool 207:73-80

Mace TF, Davis CC (1972) Energetics of a host parasite relationship as illustrated by the leech Malmiana nuda and the shorthorn sculpin Myoxocephalus scorpius. Oikos 23(3):336-343

Metcalf VJ, Gemmel NJ (2005) Fatty acid transport in cartilaginous fish: absence of albumin and possible utilization of lipoproteins. Fish Physiol Biochem 31:55-64

Milinski M (1984) Parasites determine a predator's optimal feeding strategy. Behav Ecol Sociobiol 15:35-37

Milinski M (1985) Risk of predation of parasitised sticklebacks (Gasterosteus aculeatus L.) under competition for food. Behaviour 93:203-216

Moser WE, Desser SS (1995) Morphological, histochemical, and ultrastructural characterization of the salivary glands and proboscises of three species of glossiphoniid leeches (Hirudinea: Rhynchobdellida). J Morphol 225:1-18

Editorial responsibility: Sven Klimpel,

Frankfurt, Germany
Mulcahy D, Klaybor D, Batts WN (1990) Isolation of infectious hematopoietic necrosis virus from a leech (Piscicola salmositica) and a copepod (Salminocola sp.), ectoparasites of sockeye salmon Oncorhynchus nerka. Dis Aquat Org 8:29-34

Olson KR (1999) Rectal gland and volume homeostasis. In: Hamlett WC (ed) Sharks, skates and rays: the biology of elasmobranch fishes. John Hopkins University Press, Baltimore, MD, p 329-352

Rupp RS, Meyer MC (1954) Mortality among brook trout, Salvelinus fontinalis, resulting from attacks of freshwater leeches. Copeia 294-295

Sawyer RT, Hammond DL (1973) Observations on the marine leech Caliobdella carolinensis (Hirudinea: Piscicolidae), epizootic on the Atlantic menhaden. Biol Bull 145: 373-388

> Sawyer RT, Jones CP, Munro R (1991) The biological function of hementin in the proboscis of the leech Haementeria ghilianii. Blood Coagul Fibrinolysis 2:153-159

Shuttleworth TJ (1988) Salt and water balance-extrarenal mechanisms. In: Physiology of elasmobranch fishes. Springer, Berlin, p 171-199

> Soler-Jiménez LC, Fajer-Avila EJ (2012) The microecology of dactylogyrids (Monogenea: Dactylogyridae) on the gills of wild spotted rose snapper Lutjanus guttatus (Lutjanidae) from Mazatlan Bay, Mexico. Folia Parasitol (Praha) 59:53-58

> Wood CM, Walsh PJ, Kajimura M, McClelland GB, Chew SF (2010) The influence of feeding and fasting on plasma metabolites in the dogfish shark (Squalus acanthias). Comp Biochem Physiol A Mol Integr Physiol 155: 435-444

Submitted: May 2, 2012; Accepted: July 19, 2012

Proofs received from author(s): September 28, 2012 